\title{
Navigating Ethnicity: Collective Identities and Movement Framing in Deeply Divided Societies
}

\author{
Chiara Milan (1) \\ Department of Political and Social Sciences, Scuola Normale Superiore, Italy \\ Email: chiara.milan@sns.it
}

\begin{abstract}
This article explores collective identity frames and discursive strategies employed by social movement actors mobilizing in ethnically divided societies, a context where ethnicity constitutes the primary collective category of identification. By using Bosnia and Herzegovina as a case study, it analyzes movement framing in three waves of social protests that occurred in the country in the last decade. Specifically, it investigates the diverse ways in which movement leaders tackled ethnicity in their discourses. The article shows that movement leaders' narratives rested, respectively, on the primacy of human and citizenship rights, a common feeling of deprivation, and victimhood. Their approach toward ethnicity, however, differed in each wave. Ethnicity was openly rejected in 2013, avoided and not openly contested in 2014, and accepted and approached as an opportunity to bring further support to the movement in 2018. The article highlights that ethnicity can be tackled differently by social movement actors mobilizing on nonethnic grounds in divided societies, and that it might constitute a vantage point for social mobilization rather than a drawback, contributing to raising transversal solidarity.
\end{abstract}

Keywords: ethnicity; divided societies; Bosnia and Herzegovina; movement framing; collective identity

\section{Introduction}

In January 2019, the New York Times published an article titled “In Bosnia, a Father's Grief Swells into an Antigovernment Movement" (Surk 2019). It reported the case of Davor Dragičević, a waiter and former veteran of the 1992-1995 war, who had taken to the streets of Banja Luka for months demanding justice for his 21-year-old son Davor. Davor had been found lifeless in March 2018, his death covered up by the local police. For months, Mr Dragičević occupied the main square of Banja Luka, protesting under the slogan "Justice for David" together with Davor's friends and hundreds of citizens, asking for a police investigation into the cover-up of his son's death. In December 2018, Mr. Muriz Memić and his family joined the "Justice for David" movement. A resident of Sarajevo, Memićs young son Dženan had also been found dead under similar, unclear circumstances two years earlier. ${ }^{1}$ Demonstrators and journalists alike rushed to stress that Dragičević, an "ethnic Serb," had joined hands with Memić, an "ethnic Bosniak" (Bosnian Muslim), in demanding justice and truth. David's father is a war veteran who joined the Bosnian Serb army in the 1992-1995 war, whereas Dženan's father fought on the opposite side. The picture of two bereaved fathers together demanding justice for their sons hit international headlines for its symbolism: they represented the unity of citizens of Bosnia and Herzegovina $(\mathrm{BiH})$ regardless of ethnonational allegiances. Because Davor's father is a Serb and Dženan's a Muslim, they also came to symbolize the abuse of power and

\footnotetext{
(C) The Author(s), 2021. Published by Cambridge University Press on behalf of the Association for the Study of Nationalities. This is an Open Access article, distributed under the terms of the Creative Commons Attribution licence (http://creativecommons.org/licenses/by/4.0/), which permits unrestricted re-use, distribution, and reproduction in any medium, provided the original work is properly cited.
} 
the injustice experienced equally by citizens across the country. The 2018 movement "Justice for David" (Pravda za Davida) revealed the extent to which newspapers and politicians alike tend to focus on the ethnic background of demonstrators when social mobilization occurs in ethnically divided societies such as BiH. For instance, the Spanish newspaper El Pais emphasized that the "Justice for David" movement sparked "interethnic solidarity" (Pita 2018), and the New York Times stated that the two fathers had "taken a remarkable step in crossing some of Bosnia's divisions" (Surk 2019), given that they protested together despite their different ethnic allegiances. As has frequently happened in the past, a protest evoking justice was read through lenses that highlighted the ethnic background of the protesters more than their grievances.

Yet, this case should not be surprising given that recent scholarship has challenged the assumption that an ethnically fragmented setting is unconducive to the growth of social mobilization, which suggests instead that ethnic diversity does not necessarily constitute a stumbling block for social mobilization of civic movements and parties (Murtagh 2020; Puljek-Shank and Fritsch 2019; Piacentini 2020; Milan 2020). Nonetheless, the ways in which social movement actors tackle ethnicity in their discourses has not yet been studied systematically. Consequently, it warrants further inquiry. To that end, this article attempts to fill this gap in the literature by addressing the following questions: Which discursive strategies and collective identity frames do social movement actors employ when mobilizing on nonethnic ground in ethnically divided settings? Which kind of collective identities do they activate? How do social movement actors tackle ethnicity in their mobilizing discourses? To answer to these questions, this article analyzes and compares the diverse collective identity frames, narratives, and discursive strategies put forward by movement leaders in three different episodes of social mobilization that occurred in 2013, 2014, and 2018 in $\mathrm{BiH}$. Although triggered by different events, on these occasions, citizens poured into the streets to voice their outrage at a corrupted and unaccountable elite, addressing its impunity and clientelism.

By bringing together two strands of the literature - namely, social movement studies and research on divided societies - the article enriches our understanding of social mobilization in divided settings, shedding light on the relationship between social mobilization, discursive strategies, and ethnic identity. Drawing on the existing literature and empirical data, this study offers an in-depth analysis of collective identity frames and discursive strategies used by social movement actors mobilizing on nonethnic ground in an ethnically divided context such as $\mathrm{BiH}$ over the last decade. Specifically, it illustrates their different approaches toward ethnicity. Consequently, the contribution to the literature is twofold. First, the article offers novel insights into social movement scholarship, delving into the ways in which narratives and discursive strategies are used to activate social discontent and to mobilize transversal support in divided societies, and exploring the different approaches to the issue of ethnicity. The in-depth empirical perspective on $\mathrm{BiH}$ advances our understanding of social mobilization in deeply divided societies through social movement research (Bosi and De Fazio 2017; Nagle 2008, 2016; Agarin, McCulloch, and Murtagh 2018; Murtagh 2016). Second, the analysis adds to the growing literature investigating contentious politics in the post-Yugoslav space, still an under-researched geographical area in social movement literature that so far has mainly concentrated on "stable" Western democracies (Bosi and De Fazio 2017). In fact, social movements began to play a critical role in the former Yugoslav region especially over the last decade. In addition, scholarship investigating social mobilization in divided societies has tended to neglect the Western Balkans region until recently, with some notable exceptions (Touquet 2015; Milan 2017a, 2020; Bieber and Brentin 2018).

The article proceeds as follows. First, it illustrates the main features of ethnic identity and contentious politics in divided societies. Next, it outlines the methodology and data collection methods used in this study, and it explains why $\mathrm{BiH}$ has been chosen as a case study. It then explores the collective identity frames and discursive strategies used by movement actors to mobilize bystanders throughout the three waves of protest analyzed. An investigation of the diverse approaches they have adopted toward ethnicity follows. It concludes by summarizing the most important findings of the study, reflecting on the contribution of this article to understand how 
social movement actors approached ethnicity in divided societies, and identifying paths for further research.

\section{Ethnic Identity and Social Mobilization in Divided Societies}

Several scholars have underlined that deeply divided societies are "characterized by cleavages that are not pacified, as well as by the widespread belief that the state is actively taking the side of one of the parts in conflict" (Bosi and De Fazio 2017, 11). One of the main features of divided societies is that the legitimacy of the state is questioned, being perceived as "acting in favour of a portion of society, rather than for all its citizenry" (Bosi and De Fazio 2017, 11). A low level of trust among ethnonational groups undermines social cohesion while the struggle for statehood dominates the political scenario. In societies deeply fragmented along ethnonational lines, social and civic life tends to occur within, rather than across, so-called ethnic cleavages while "all politics are practically subsumed by the wider ethnopolitical conflict over state legitimacy" (Nagle 2016, 47). Both the institutional design and political landscape of divided societies, dominated by ethnic parties, leave little room for "alternative modes of politics that cross-cut ethnic cleavages" (Nagle 2017, 185), while subcultural divisions tend to increase the propensity to political violence and state repression (Nagle 2017).

To foster democratic governance in deeply divided societies, diverse models of power-sharing have been implemented, with provisions aimed at granting political stability and accommodating the interests of diverse ethnonational groups. Among those, consociationalism is a type of powersharing that ensures joint governance by agreeing to proportional representation and participation of the major ethnic groups in the state's bodies and institutions, as well as ethnicity-based veto powers (Lijphart 1969). By facilitating direct representation of ethnic groups in institutions and in the government, consociationalism renders them the main building blocks of the political system (Touquet 2011). In so doing, this model provides "strong preference of collective rights of ethnic groups to the detriment of individual citizens" (Mujkić 2008, 17). It consequently encourages identification with the ethnic kin rather than with the state, curtailing the space for alternative views of political belonging that are not predominantly ethnic (Nagle 2016).

In terms of political representation, consociationalism renders ethnonationalist parties the most preferred option in the ballot box, excluding or underrepresenting individuals who choose on a non-ethnic base (Agarin, McCulloch, and Murtagh 2018). Therefore, civic or multiethnic parties find it difficult to gain an electoral foothold (Piacentini 2019a; Touquet 2011; Murtagh 2020). The system incentivizes voters to cast their preferences along ethnic lines because it offers "little incentive to the representatives of the main ethnopolitical cleavage to facilitate the representation and participation of the Others" (Agarin, McCulloch, and Murtagh 2018, 304). In such an environment, the most salient political identity of citizens "is the one accommodated in the consociational structure" (Agarin, McCulloch, and Murtagh 2018, 301). Ethnic identity is therefore privileged over nonethnic, transethnic identities, and other forms of identity, such as gender and class. Cross-cutting and alternative forms of identity are marginalized (Agarin, McCulloch, and Murtagh 2018; Agarin and McCulloch 2020) while the space for civil mobilization is limited (Kennedy, Pierson, and Thomson 2016). Consequently, ethnic identities stand as "central organizing principles for contentious politics" (Bosi and De Fazio 2017, 25).

Social movement actors mobilizing in this context encounter a number of drawbacks to their initiatives, which stem from the structural, political, and cultural milieu in which they operate. Incumbents repeatedly taint political opponents as traitors who are disloyal to the nation and their ethnic kinship, denying them any legitimacy (Bieber 2019), thereby discouraging social mobilization. Activists and political opponents are constantly the target of smear campaigns blaming them for ethnic disloyalty and discrediting them for being paid by foreigners to threaten national unity and authenticity (Jansen 2016) while the ethnic background is frequently used to discredit political opponents and demonstrators - a condition that fosters "almost any contention into the terms of 
the (identitarian) legitimacy of the state's existence" (Jansen 2018, 59). Furthermore, in this context, "competing ethnic or national identities can be activated and made salient in a short period of time" (Bosi and De Fazio 2017, 17). In addition, in places such as $\mathrm{BiH}$, taking to the streets as a sign of protest is likely to either undermine the possibility of securing employment in the public sector or put at risk an existing position (Brković 2017), given the strength of ethno-clientelistic networks that informally regulate the job market. Fear of disorder and instability, associated with war memories, discourage people from taking to the streets while the level of repression exercised against political opponents is still high throughout the country.

In spite of divided societies offering more incentives for ethnic than for nonethnic mobilization (Agarin, McCulloch, and Murtagh 2018), recent scholarship has shown that both political parties and social movements having nonethnic or multiethnic character emerge in divided societies. In fact, identification along ethnic lines does not directly imply that one would necessarily vote for one's coethnics or pursue narrow ethnic agendas. Over the last decade, citizens of $\mathrm{BiH}$ have taken to the streets in several cases for causes that had no ethnic character (Milan 2020; Touquet 2015; Nagle 2016; Milan 2017a). Similarly, civic mobilizations occurred in divided contexts governed under ethnic power-sharing mechanisms such as North Macedonia (Pollozhani 2016; Piacentini 2019b; Stefanovski 2016), Lebanon (Nagle 2017), Iraq (Costantini 2020), and Northern Ireland (Nagle 2008). Several scholars have called into question the notion that ethnically divided contexts, which encourage the institutionalization and reification of ethnic identities, necessarily represent a drawback for social mobilization having nonethnic connotations (Milan 2020; Murtagh 2020; Puljek-Shank and Fritsch 2019; Piacentini 2020). These sources disclosed that ethnic diversity might even constitute a vantage point for civic parties and social mobilizations. For instance, Murtagh (2020) contends that power-sharing institutional systems can provide civil parties with critical openings, not only with barriers, for nonethnic representation. In their analysis of the 2014 uprising in BiH, Puljek-Shank and Fritsch (2019) maintain that social movement actors gathered broad support across the country thanks to the antipolitical discourse they put forward, which intentionally opposed both ethnonational and neoliberal discourses. Milan (2020) has shown that inadequate resources, fear of insecurity, and movement framing - more than ethnic allegiances hindered the level of support for social movements mobilizing in $\mathrm{BiH}$. Along similar lines, Piacentini (2019a) suggested that the consolidation of ethno-clientelistic alliances between ethnonationalist parties and the ethnicized masses curtails the level of electoral support for civic political parties more than the highly ethnized state structure.

Based on episodes of social mobilization that occurred in the last decade in $\mathrm{BiH}$, in what follows, I explore the different discursive strategies and frames employed by social movement actors to appeal to and attract support from the broader society. Specifically, I look at how activists and social movement actors tackled ethnic identity in the different collective identity frames they put forth throughout their protests. In this way, I show that ethnicity can be sidelined by social movement actors but that it might also be explicitly addressed as an opportunity that constitutes a potential resource for mobilization.

\section{Methodological Note}

The study draws on a set of data collected between 2013 and 2019, which includes qualitative interviews and participant observation of protest activity in 2013 and 2014. I conducted around 20 in-depth semistructured interviews with activists and social movement organizers who played leading roles in the 2013, 2014, and 2018 waves of protests. The interviews were carried out in Bosnia and Herzegovina -specifically in the cities of Sarajevo, Banja Luka, Tuzla, Zenica, and Mostar - in different rounds of fieldwork in 2013, 2014, 2015, and 2019, respectively. In addition to speaking with activists and movement organizers, I also carried out informal talks with experts and key respondents. In most cases, the respondents, both male and female, are long-term activists, over 20 years of age, and they were identified using a snowball sampling technique. The majority had 
participated in more than one wave of protests, taking part in demonstrations that occurred prior to 2013 (such as those of the Dosta! [Enough!] movement and the 2008 protest for security in Sarajevo). Many interviewees are employed in the third sector, including international NGOs, and they hold key positions not only in the protest movements but also, frequently, in the domestic cultural scene. The topics tackled by the interviews ranged from the repertoires and tactics used during the protests - specifically, the narratives and discursive strategies employed to frame the issue at stake - to personal perceptions of the resonance (or lack thereof) of their discourses with the wider population. Other questions delved into the challenges that derive from mobilizing in an ethnically fragmented context, related to structural, cultural, and discursive issues. In addition, I have closely examined the content of websites and social media material, including press releases, communiqués, flyers, slogans, movements' manifestos, and documents, as well as media statements published on alternative social media in both the local language and English.

$\mathrm{BiH}$ has been chosen as a case study because it represents a case in point for the investigation of social mobilization in divided societies. The country is deeply divided along ethnonational lines and is governed according to a corporate consociational model of power-sharing. Ethnonational categories are fixed to the extent that they have been institutionalized in the Constitution. Ethnic politics dominates the political scene, given that the consociational design benefits political parties mobilizing around ethnic and nationalist platforms (Touquet 2011), encouraging citizens to vote along ethnonational lines. Nonetheless, the country has a long history of multiethnic cohabitation: during socialist rule, different national communities inhabited its territory. Unlike other former Yugoslav republics, though, $\mathrm{BiH}$ did not have an ethnonational majority (Keil 2013). Between 1992 and 1995, the country experienced a violent conflict that featured ethnic elements. Several mobilizations have occurred in the last decade, and the use of street protests has been normalized over time, as the next section elucidates.

\section{Social Mobilization beyond Ethnicity in Bosnia-Herzegovina}

Sustained episodes of grassroots collective action emerged and spread in the country in the last decade, all having the political elite in common as a target. $\mathrm{BiH}$ faced democratic turmoil on several occasions, when citizens expressed open dissent toward their political establishment by means of street protests, which in some cases turned into open violence (Milan 2020). Often addressing the rising level of unemployment and the corruption of political incumbents, demonstrators targeted government buildings and other symbols of power, at times violently. Because the grievances voiced in the streets overarched ethnonational allegiances, these waves of protest qualify as "beyond ethnicity" (Milan 2020). Over the last decade, three protest waves became widespread in the country: in 2013, protestors occupied the square in front of the National Parliament in Sarajevo; in 2014, enraged citizens vandalized several governmental edifices; and in 2018, rallies organized to demand justice and truth about the death of a young student under unclear circumstance were met by police violence. Although other protests also swept the country, those that occurred in 2013, 2014, and 2018 distinguish themselves in three ways: they spread almost nationwide, demonstrators' grievances were not based on nationalist considerations, and the political leaders represented the target of protests. Throughout these episodes, protest leaders utilized collective identity frames that did not revolve around the primacy of ethnic identity, privileging instead other types of identities. Their discourses did not align with the dominant ethnonational frame, but deliberately supplanted and, at times, clashed with it. As regards grievances, on the streets, citizens decried the increasingly authoritarian tendencies of their leaders, demanded (1) accountability on the part of the political elite, (2) a government that is responsive to citizens' needs and problems, (3) respect for democracy and adherence to the law by public authorities and officials, and (4) the adoption of anticorruption provisions. The slogans and placards carried on the streets referred to politicians as "thieves and criminals," pointing to an unaccountable elite stealing from its constituencies. 
The 2013 Babylution, a term that means "the revolution of babies," consisted of a series of protests that took place mainly in Sarajevo between June and July 2013. Solidarity rallies were also staged in the cities of Mostar, Tuzla, and other urban centers of the country. The unrest was sparked by the case of a seriously ill three-month-old baby girl unable to travel to receive medical treatment abroad. She was prevented from leaving the country due to the lack of an ID number, without which she was unable to obtain a passport. This deadlock stemmed from the temporary absence of a national Law on Identification Numbers, erased by the Constitutional Court following a political disagreement among members of Parliament (MPs). Because the registration of newborns had been frozen as of February 13, 2013, any passports and personal documents necessary to travel abroad could not be released to children born after that date (Armakolas and Maksimović 2013; Milan 2017a; Kurtović and Hromadžić 2017). Touched by the case, several citizens of Sarajevo, organized and coordinated through Facebook, assembled in front of the National Parliament on the morning of June 5. The group organized a car blockade as a sign of protest, thereby preventing MPs from leaving the building. Although a temporary solution for the baby girl was found in the afternoon of June 6, that night, the demonstrators organized a "siege" of the Parliament building by forming a human chain that surrounded the venue (Milan 2017b). Nearly 1,500 people - including civil servants, MPs, and foreign investors who happened to be inside the building - were allowed to leave only at dawn. The demonstrators occupied the square in front of the Parliament for 25 consecutive days, unsuccessfully demanding the resignation of incumbents.

Seven months later, in February 2014, another wave of protest arose in the city Tuzla, a former industrial hub located in northeastern $\mathrm{BiH}$. Termed "Social Uprising," this wave of mobilization was much more violent than the previous one. The unrest was triggered by a group of workers who had been laid off by factories that had been privatized and then shut down as a consequence of the mishandled privatization and mismanagement of the new owners, who often acted in cahoots with the local political elite (Pugh 2005; Calori 2015). Following a violent police crackdown on demonstrators, the rally spiraled out of control and spread to the main urban centers and towns across the country (Milan 2020; Murtagh 2016; Mujanović 2018). Soon, people of all ages and walks of life joined the demonstrations. In an escalation of violence, town halls, government buildings, and the headquarters of the nationalist parties were set ablaze by the enraged crowd. The upheaval caused a sequence of high-level resignations of policy officials and brought about the formation of citizens' assemblies called "plenums." Open to the participation of citizens, plenums functioned according to a direct democratic method of decision-making (Milan 2020; Arsenijević 2014). After months of demonstrations and street marches, protests and plenum activity came to a final halt around mid-May 2014.

In 2018, the movement "Justice for David" hit the international headlines. In March of the same year, David Dragičević, a 21-year-old graduate student of Banja Luka, had been found dead under suspicious circumstances. The alleged cover-up of David's death by the local police triggered longrunning protests and a campaign demanding truth and justice for the young student. The 2018 protests started in Banja Luka, the capital of Republika Srpska, ${ }^{2}$ and from there they spread to the Federation of $\mathrm{BiH}(\mathrm{FBiH})$. Until then, the opposite had occurred: protests that were sparked in Sarajevo or Tuzla (therefore, in $\mathrm{FBiH}$ ) had received support from some citizens of the Republika Srpska, usually by means of small-scale solidarity rallies. Political opponents in the Republika Srpska are generally exposed to stronger repression than in $\mathrm{FBiH}$, and prior to 2018, the only remarkable mobilization in Banja Luka had been provoked by the dismantling of a public park in 2012 (Milan 2020; Wimmen 2018). On April 21, 2018, about 10,000 people gathered together in the main square of Banja Luka asking for justice (Sasso 2018b). The demonstrators grew in number until they reached 40,000 on the eve of the general election in October, a remarkable figure for Banja Luka (Lazarević 2019). A police attack on the demonstrators in Banja Luka on December 25 brutally halted the protests. The crackdown was followed by the arrest of activists and leaders of the movement, including David's father. Davor Dragičević, the most outspoken and visible figure of the protests, openly accused the authorities of Republika Srpska of concealing the murder of his son for 
political reasons (Surk 2019). After nine months of rallies and gatherings, the "Justice for David" movement came to a halt.

Throughout the three protest waves, movement leaders called for social justice, as well as for the respect of human and citizenship rights. They strove to reach out to their fellow citizens by advocating for issues of common interests without addressing bystanders as members of a specific ethnonational group. In their discursive practices, movement actors campaigned to make common grievances and concepts such as social justice and good governance salient, and they eschewed accusations of being "ethnically driven." Throughout these waves of mobilization, social movement actors thus privileged "the participation of the person - the citizen, the member of the community" (della Porta 2015, 187) over ethnic allegiances. In their discourses, they pointed at an overarching collective identity that transcended, and occasionally challenged, the constituents' ethnic categorization. Whereas previous studies have addressed and explored the collective identity frames adopted by social movement actors (Milan 2020; Murtagh 2016; Touquet 2011, 2015), none so far has focused on how protest leaders approached and articulated ethnicity in these discourses. The next section addresses this gap by exploring how social movement leaders have tackled ethnicity in the collective identity frames they put forward throughout their mobilizations.

\section{Navigating Ethnicity: Discursive Strategies and Collective Identity Frames in Divided Societies}

Throughout the protests analyzed, movement actors interpreted and voiced people's discontent in a way that aimed to attract the widest support, constructing collective identities and systems of meaning (Snow et al. 1986) that were likely to resonate with the domestic cultural environment. In social movement literature, framing activity refers to the process of attribution of meaning that groups and individuals give to symbols, events, and discourses (Goffman 1986), which motivate support for collective action. Frames are "schemata of interpretation" (Goffman 1974, 21) that movement leaders construct and use to make sense of reality in a way that prompts people to take action, persuading bystanders of the importance and righteousness of their cause (Benford and Snow 2000). In this study, I look specifically at the collective identity frames that social movement organizers employed to "distinguish bystanders from opponents" (Polletta and Jasper 2001, 292) throughout the three waves of protests. This "us" versus "them" categorization is used by movement organizers to "define their enemies by their real or imagined attributes and evils" (Tarrow 2011, 31). As previous studies pointed out, collective identity is a process rather than a property of social actors (Snow and Corrigall-Brown 2015), the product of meanings that human beings ascribe to certain differences. Identities can be multiple, multilayered, fluid, and evolving rather than fixed and firmly rooted (Fearon and Laitin 2000). As prominent scholars have suggested, ethnic identity is socially constructed and historically reproduced (Anderson 1991; Brubaker 2004). Therefore, movement leaders might articulate and prioritize some collective identities over others, making them salient over time. Through narratives and discursive practices, they can create alternative collective identities, meaning “individuals' cognitive, moral and emotional connection with a broader community, category, practice, or institution” (Polletta and Jasper 2001, 285).

In the three protest waves analyzed, movement leaders endeavored to build a collective sense of unity and solidarity among individuals that prioritized some identities over others. In what follows, I identify and compare the diverse frames and discursive strategies that social movement actors have employed to create a shared and overarching sense of belonging. In particular, I focus on their positioning toward ethnic identity, exploring the way they approached ethnic identity in their narratives. I have categorized three collective identity frames, corresponding to three different approaches toward ethnicity, as summarized in table 1 below:

In the three protest waves, movement leaders resorted to diverse discourses to mobilize bystanders. For the sake of comparison, I named these three types of collective identity frames as follows: "human beings," "hungry people (gladni narod)," and "victims of injustice." In each case, 
Table 1. Collective Identity Frames in Three Protest Waves beyond Ethnicity

\begin{tabular}{lll}
\hline Protest wave & Collective identity frame & Approach toward ethnicity \\
\hline 2013 Babylution & Human beings & Rejected and openly challenged \\
\hline 2014 Social Uprising & Hungry people & Avoided, not openly contested \\
\hline 2018 Justice for David & Victims of injustice & Accepted, approached as an opportunity \\
\hline
\end{tabular}

ethnic identity was approached differently. In the 2013 Babylution, ethnicity was rejected and openly challenged. In the 2014 Social Uprising, it was intentionally disregarded, but not openly contested. And in the 2018 mobilization, it was accepted and approached as an opportunity to raise transversal solidarity, as I explain in the next sections.

\section{United in Humanity: The "Human Beings" Frame and the Rejection of Ethnicity}

Throughout the 2013 Babylution, movement organizers purposely focused their discourses on the primacy of human and citizenship rights, lamenting the unaccountability of their political elite (Milan 2017a). In so doing, they endeavored to counterbalance the attempts of politicians to discard the Babylution as motivated by ethnic animosity. Movement leaders did so by framing the lack of ID papers for babies as a violation of human rights. Yet, this was not the first time that this type of discourse was used. The "human beings" frame might be considered an evolution of the discursive narrative employed throughout the 2008 protests for security in Sarajevo, sparked by the killing of a young man on a tram there. On that occasion, movement leaders employed what has been called the "gradanin (citizen) frame" (Touquet 2015), a discourse that revolved around the primacy of the city-dweller or citizen identity (gradan in the Bosnian/Croatian/Serbian language) over ethnonational allegiances. The emphasis was consequently put on a nonethnic social cleavage, given that the discourse of movement leaders placed the secular and better-educated citizen in opposition to the uninformed villager (seljak), considered more easily prone to nationalism (Jansen 2005).

In 2013, movement leaders elaborated on this frame by stressing the value of citizenship even further. Throughout the 2013 mobilization, they presented and framed the demonstrators as a loose group of individuals, who refused any kind of labeling in terms of institutionalized, and instrumentally used, ethnonational categories. By resorting to this discourse, movement organizers set themselves apart from any political parties or nongovernmental organizations (NGOs) ${ }^{3}$, which in the country are widely associated with foreign intervention, amorality, and irresponsibility (Helms 2007; Touquet 2012). They therefore portrayed themselves as "morally pure." On the website of the movement, the organizers of the Babylution framed their identity as citizens of Bosnia and Herzegovina, detached from political affiliation or membership in NGOs or formal associations. They claimed to be simply "individual citizens with full first and last name," mobilizing for human rights "regardless of ethnic or religious background or any other status," as the movement's manifesto reported (“\#JMBG Manifesto” 2013).

As the protests unfolded, movement leaders represented demonstrators as first and foremost "human beings," making explicit that they rejected ethnonational identification. The placards carried on the streets displayed slogans such as "Neither Serbs, Croats nor Bosniaks: Human beings first," "Death to nationalism. This is civil BiH!" and "Fuck the three constituent peoples, start working!" - a slogan addressing the political elite. As opposed to immoral politicians, the citizens of $\mathrm{BiH}$ were represented as human beings who "took the moral high ground by embracing nonviolence" (Simpson 2013). Movement leaders therefore chose to emphasize a moral cleavage that set citizens against the political elite, the latter depicted as corrupt and immoral, which resorted to ethnicity as a mechanism to polarize individuals of different affiliations (Garić-Humphrey 2020). This sharp, moral differentiation was visible on a placard that read, "We are people, not 
parliamentarians" (Ljudi smo, nismo parlamentarci). According to the leading organizers, throughout the 2013 Babylution, their approach toward ethnicity was one that openly and intentionally rejected it in favor of a collective "human beings" identity that did not envisage ethnonational affiliations.

\section{United in Deprivation: The "Hungry People" Frame and the Avoidance of Ethnicity}

The mobilizing discourse employed throughout the 2014 Social Uprising connected the widespread discontent of $\mathrm{BiH}$ citizens with socioeconomic arguments, such as the corruption of political leaders and the theft they committed since taking office. From the very beginning of the protests, movement leaders framed the collective "we" in terms of the "hungry people" (gladni narod), united in solidarity and by deprivation, regardless of ethnonational belonging. The sense of betrayal and disillusionment toward the seemingly endless transition of the country to a market economy and liberal democracy, which did not bring about the socioeconomic changes that citizens expected, was expressed in the definition of $\mathrm{BiH}$ citizens as "transition losers." ${ }^{4}$ As was the case with the discourse adopted in the previous wave of protest, the narrative held a strong moral component. The demonstrators, identified with the "affectively charged term 'the people' (narod)" (Jansen 2018, 58), were portrayed as encompassing the inherently good population, framed in nonidentitarian terms. By contrast, the ruling elites were derogatorily "referred to mainly as političari (politicians)" (Jansen 2018, 58). The discourse of social justice resonated with bystanders, who considered themselves betrayed by the incumbents. In this case too, activists adopted a dichotomizing narrative that starkly opposed the mass of dissatisfied citizens against the corrupt and unaccountable elites, without reference to any ethnonational identitarian concerns.

To convey their message, activists resisted the attempts to reconfigure the issue at stake as a call to end the ethnic power-sharing mechanism, in favor of a strategic focus on socioeconomic justice. They deliberately chose not to tackle the rights of constituent peoples or to question the provisions of the Dayton ${ }^{5}$ agreement to avoid the accusation of ethnic partiality that could defuse the movement. ${ }^{6}$ Consequently, in their discourses, they strategically focused on the values of "unity" and "togetherness" at the basis of their claims. These values were emphasized on banners on the streets bearing slogans such as "All for one and one for all" (Svi za jednog jedan za sve) and "Our union is your destruction" (Naše ujedinjenje je vaše uništenje), which aimed at portraying ordinary citizens united in solidarity regardless of ethnonational cleavages and against the political class. Ethnonational allegiances were consequently sidelined in the narratives in the name of a "common enemy": the corrupt establishment, immune to accountability. This collective identity frame pointed to the emergence of a new cleavage that overcame the dominant ethnonational categorization by disregarding it, prioritizing instead the common experience of deprivation and a call for social justice. A placard raised on the streets of Sarajevo, which became viral throughout the protests, read "We are hungry in three languages" (Gladni smo na tri jezika). The slogan intended to ridicule the institutionalization of ethnonational categories in the country, which was blamed for dividing - along ethnonational lines - individuals who all faced the same problems in everyday life and were therefore "united in deprivation."”

\section{United in Grief: The "Victims of Injustice" Frame and the Acceptance of Ethnicity as Opportunity}

People of all ages participated in the "Justice for David" demonstrations, from David's friends in Banja Luka to young and older people across the country. The movement gained momentum when it was discovered that David's death was just one of the many "silenced deaths" - meaning unsolved cases of violent casualties probably covered up by domestic authorities (Sasso 2018a). In an attempt to widen the front and broaden the support base of the movement, Davor Dragicević and the "Justice for David" movement built an alliance with the father of Dženan Memić, another "silenced case" of Muslim background. The diverse ethnic background of the two fathers made it harder to 
discredit the protests as ethnically driven. Moreover, David's father had no prior experience with political activity, and he had also served the army of Republika Srpska during the 1992-1995 war. Given his status of war veteran, it was more difficult for nationalist leaders to discredit him as a traitor or as someone disloyal to the nation. Also, the social milieu that gave birth to the protests was different. Whereas the 2013 Babylution emerged from the NGO environment, the 2014 protest had a strong workers' component, although it was highly populated by urban youth. In contrast, the organizers of the 2018 protests had little or no prior experience in the third sector, NGOs, or political activism. Consequently, they could not be accused of being "paid by foreigners" to disrupt the stability of the country.

The discourses employed throughout the 2018 protests revolved around what Helms referred to as the "perennial narrative" of innocence and victimhood (Helms 2013). On many occasions, the two fathers stated publicly that ethnicity and religion had no relevance in their struggle because David was "a Serb killed by Serbs," and Dženan "a Muslim killed by Muslims" (Sasso 2019). The support for "Justice for David" was transversal, given that movement leaders framed the issue at stake as a matter of justice and depicted the citizens of $\mathrm{BiH}$ as equally victims of the elites and the police, regardless of ethnic background. This discourse succeeded in increasing support from the population at large and fueling rage against the incumbents. The campaign obtained strong resonance throughout $\mathrm{BiH}$, an environment particularly sensitive to issues concerning justice for young and innocent victims (Helms 2007) like David and Dženan. According to some, the "Justice for David" movement managed to unite people in grief, building solidarity across entities and ethnic cleavages (Zuvela 2018) in a way that possibly no previous protest movement had managed to do.

The emotional drive that the death of the two young students provoked contributed to conveying rage and indignation toward the political elite, who were blamed for concealing the murders. Aside from the emotional drive, both campaigns also resonated with the fear of insecurity and instability pervasive among the $\mathrm{BiH}$ population (a legacy of the war) and with the "moral purity" of their demands (justice and truth for innocent victims). The stance of social movement organizers rendered the protests classifiable as "nonpolitical," which made them less likely to be exploited or hijacked by political parties, and also less prone to be accused of representing ethnic or religious partiality. Consequently, the mobilizing discourse adopted throughout the "Justice for David" protests tapped into the moral indignation derived from the unsolved murder and rapidly turned into indignation stemming from the corruption and impunity of the political leaders, who were in cahoots with the police. With regard to the attitude toward ethnic identity, it was navigated in a way that garnered broader support for the movement. The heterogeneous ethnic background of both affected persons and demonstrators was approached as an opportunity that constituted a potential resource for mobilization due to the fact that citizens with diverse ethnic backgrounds had experienced the same injustice, thereby generating transversal support for the cause.

\section{Conclusions}

This article has explored different collective identity frames and discursive strategies used by social movement actors mobilizing on nonethnic grounds in divided societies. Specifically, it has examined the ways in which social movement actors approached ethnicity. By using Bosnia and Herzegovina as a case study, this article has improved our understanding of social mobilization in divided societies - a context where ethnicity generally constitutes the primary collective category of identification - while also adding to the literature dealing with contentious politics in the postYugoslav space. By investigating different types of collective identity frames that movement actors articulated to bring further support to their cause, the study sheds light on the variations in deployment of references to ethnicity in nonethnic social mobilizations that have occurred in deeply divided societies.

In the waves of protests analyzed, the narratives of movement leaders that were used to mobilize bystanders rested, respectively, on the primacy of human and citizenship rights, a common feeling 
of deprivation, and victimhood. Yet, the way ethnicity was approached in the discourses differed: it was rejected and openly challenged in the 2013 Babylution, avoided but not openly contested in the 2014 Social Uprising, and accepted and approached as an opportunity in the 2018 "Justice for David" movement. In the case of "Justice for David," ethnic diversity was tackled in a way that constituted a vantage point for the movement because it contributed to sparking transversal solidarity. Building on recent scholarship suggesting that ethnically divided settings do not necessarily represent a stumbling block for social mobilization, this study clarifies that mobilizing in a deeply divided society does not necessarily represent a drawback for social movements and that it can constitute a potential resource for mobilization.

By analyzing the case of social mobilization in $\mathrm{BiH}$, the study has highlighted the fact that social movement leaders in divided societies mobilize bystanders by using discourses that tap into a sense of injustice and that resonate with fellow citizens' emotions and lived experience of victimhood and deprivation. Some common elements can be identified in the different collective identity frames used throughout the protests: all are grounded in a sense of injustice and deprivation; the narratives identify the corrupt establishment as main culprit, and they emphasize a social cleavage with honest citizens on one side and a dishonest political class on the other; and the discourses employed retain a strong moral component. The analysis has also shown that movement actors tried to convince bystanders to take to the streets by resorting to discursive strategies that stressed unity and solidarity among people grounded in a common sense of deprivation, disillusionment, and distrust toward the ruling elite. This component is present in each of the three different identity frames put forward during the protests and is coupled with an emphasis on political neutrality (although it would be more correct to call it "partisanship"). This meant that movement actors proudly stressed the absence of any ties with political parties, NGOs, or other institutional actors, in the assumption that "politics is a dirty matter." By using these narratives, movement organizers strove to make the collective identity frames resonate with the members of the broader population, who felt deprived, dispossessed, or disempowered, regardless of their ethnonational background.

To conclude, the findings of this article suggest that the relationship between social mobilizations and ethnicity warrants further systematic inquiry. We still need to explore whether similar discursive strategies have been used in other ethnically divided societies, for instance. Further research will investigate in depth the encompassing narratives and discursive strategies employed by social movement actors in divided societies beyond the Western Balkans region, such as the Middle East (Lebanon, Iraq) and Western Europe (Ireland). Additional studies might consider exploring whether similar frames and discursive strategies could contribute to explaining the emergence and occurrence of social mobilization in these milieus.

Acknowledgments. The author wishes to thank Irene Costantini, Timofey Agarin, and Stefania Milan, as well as the participants of the ASN European Conference 2018 "Nationalism in Times of Uncertainty," which was held at the University of Graz, for their comments on a previous version of this article. Part of the research has been conducted at the University of Graz, and the author has changed the affiliation in the meantime.

Financial Support. This project has received funding from the European Union's Horizon 2020 research and innovation programme under the Marie Skłodowska-Curie grant agreement N. 792782. Data collection was in part supported by the European University Institute - PhD Grant conferred by the Italian Ministry for Foreign Affairs.

Disclosures. None.

\section{Notes}

1 Like David, the 22-year-old Dženan died from wounds following a car crash in Sarajevo in 2016. According to his family and to independent media, the accident was a murder disguised as a car accident. In both cases, police officers had provided incomplete explanations, often contrasting with the one put forth by family members and independent journalists. 
2 Nowadays, $\mathrm{BiH}$ is a decentralized state divided into two entities: Republika Srpska, which is inhabited mostly by Serbs, and the Federation of Bosnia and Herzegovina (FBiH), where mainly Croats and Bosniaks live. $\mathrm{FBiH}$ is further divided into 10 cantons, each with its own government holding broad competences. Republika Srpska is a more centralized and monoethnic entity. Each ethnic group holds veto rights when it comes to voting for issues considered to be threatening to the "vital national interest," and political participation of citizens is determined by their ethnicity (Bieber 2005).

3 Although the majority of movement leaders were employed in the third sector as NGO workers or practitioners, throughout the protests, they strove to oppose the accusation that they were "foreign mercenaries" (Razsa 2015, 64) paid by international donors to organize street protests.

4 Anonymous activist and member of plenum Sarajevo. 2014. Interviewed by author. April. Sarajevo.

5 The Dayton Peace Accords, named after the city in the US state of Ohio where the agreement was signed in 1995, brought the 1992-1995 conflict to a halt, setting up $\mathrm{BiH}$ as a consociational democracy and a triple power-sharing system. In this system, three constituent groups (Bosniaks, Serbs and Croats) are granted proportional representation through a system of ethnic quotas. The internationally sponsored peace agreement put a halt to the conflict by recognizing and strengthening the power of the main ethnic groups, on the assumption of their homogeneity. The current constitutional set-up grants equal rights and proportional representation to the three constituent nations living in the territory. The so-called "constituent peoples" share one language but hold different religious traditions: Bosnian Serbs are Eastern Orthodox, Bosnian Croats are Catholic, whereas Bosniaks (the denomination in place since 1993) are Muslim.

6 Anonymous activist and member of plenum Sarajevo and Prijedor. 2014. Interviewed by author, April. Sarajevo.

7 Anonymous activist and member of plenum Tuzla. 2014. Interviewed by author, April. Tuzla.

\section{References}

“\#JMBG Manifesto.” 2013. http://www.jmbg.org/jmbg-manifesto/. (Accessed November 4, 2015.)

Agarin, Timofey, and Allison McCulloch. 2020. "How Power-Sharing Includes and Excludes Non-Dominant Communities: Introduction to the Special Issue.” International Political Science Review 41 (1), 3-14. London: Sage Publications.

Agarin, Timofey, Allison McCulloch, and Cera Murtagh. 2018. "Others in Deeply Divided Societies: A Research Agenda." Nationalism and Ethnic Politics 24 (3): 299-310.

Anderson, Benedict. 1991. Imagined Communities: Reflections on the Origin and Spread of Nationalism. Brooklyn, NY: Verso.

Armakolas, Ioannis, and Maja Maksimović. 2013. “'Babylution': A Civic Awakening in Bosnia and Herzegovina?” Hellenic Foundation for European and Foreign Policy 34: 3-11. http://www.eliamep.gr/wp-content/uploads/2013/08/34_2013_WORKING-PAPER__Armakolas-11.pdf.

Arsenijević, Damir. 2014. Unbribable Bosnia. The Fight for the Commons. Southeast European Integration Perspectives. BadenBaden, Germany: Nomos Verlagsgesellschaft.

Benford, Robert D., and David A. Snow. 2000. "Framing Processes and Social Movements: An Overview and Assessment." Annual Review of Sociology 26 (1): 611-639.

Bieber, Florian. 2005. Post-War Bosnia: Ethnicity, Inequality and Public Sector Governance. New York: Palgrave Macmillan.

Bieber, Florian. 2019. The Rise of Authoritarianism in the Western Balkans. London: Palgrave Macmillan.

Bieber, Florian, and Dario Brentin, eds. 2018. Social Movements in the Balkans: Rebellion and Protest from Maribor to Taksim. London: Routledge.

Bosi, Lorenzo, and Gianluca De Fazio. 2017. The Troubles in Northern Ireland and Theories of Social Movements. Amsterdam: Amsterdam University Press.

Brković, Čarna. 2017. Managing Ambiguity: How Clientelism, Citizenship, and Power Shape Personhood in Bosnia and Herzegovina. New York: Berghahn Books.

Brubaker, Rogers. 2004. Ethnicity without Groups. Cambridge, MA: Harvard University Press.

Calori, Anna. 2015. "Salt and Socialism: A Deconstruction of Tuzla's Political Identity in the Context of the Bosnian Conflict." Ethnopolitics Papers, May.

Costantini, Irene. 2020. “The Iraqi Protest Movement: Social Mobilization amidst Violence and Instability.” British Journal of Middle Eastern Studies. 1-18. 
della-Porta, Donatella. 2015. Social Movements in Times of Austerity: Bringing Capitalism Back into Protest Analysis. Cambridge, UK; Malden, MA: Polity Press.

Fearon, James D., and David D. Laitin. 2000. "Violence and the Social Construction of Ethnic Identity." International Organization 54 (04): 845-877. http://journals.cambridge.org/abstract_S0020818300441226. AQ: Is URL necessary?

Garić-Humphrey, Nataša. 2020. “Negotiating 'True’ Politics: Intergenerational Dynamics during Social Uprising in Sarajevo, Bosnia-Herzegovina." PoLAR 43 (1), 69-86.

Goffman, Erving. 1974. Frame Analysis: An Essay on the Organization of Experience. New York: Harper Colophon.

Goffman, Erving. 1986. Frame Analysis: An Essay on the Organization of Experience. Boston: Northeastern University Press.

Helms, Elissa. 2007. "Politics Is a Whore': Women, Morality and Victimhood in Post-War Bosnia-Herzegovina." In The New Bosnian Mosaic: Identities, Memories and Moral Claims in a Post-War Society, edited by Xavier Bougarel, Elissa Helms, and Gerlachlus Duijzings, 235-253. Aldershot: Ashgate Publishing.

Helms, Elissa. 2013. Innocence and Victimhood: Gender, Nation, and Women's Activism in Postwar Bosnia-Herzegovina. Critical Human Rights. Madison, WI: University of Wisconsin Press.

Jansen, Stef. 2005. Who's Afraid of White Socks? Towards a Critical Understanding of Post-Yugoslav Urban Self-Perceptions. Ethnologia Balkanica 9: 151-167. http://personalpages.manchester.ac.uk/staff/stef.jansen/documents/SJ-whitesocks.pdf.

Jansen, Stef. 2016. “Cosmopolitan Openings and Closures in Post-Yugoslav Antinationalism.” In Cosmopolitanism in Practice, edited by M. Nowicka and M. Rovisco, 75-92. London and New York: Routledge.

Jansen, Stef. 2018. “Reconfiguring 'the People?' Notes on the 2014 Winter Revolt in Bosnia and Herzegovina.” In Worldwide Urban Mobilizations. Class Struggles and Urban Commoning, edited by Don Kalb and Massimiliano Mollona, 52-72. New York and Oxford: Berghahn Books.

Keil, Soeren. 2013. Multinational Federalism in Bosnia and Herzegovina. Farnham, UK: Ashgate.

Kennedy, Ronan, Claire Pierson, and Jennifer Thomson. 2016. “Challenging Identity Hierarchies: Gender and Consociational Power-Sharing." The British Journal of Politics and International Relations 18 (3), 618-633. London: Sage Publications.

Kurtović, Larisa, and Azra Hromadžić. 2017. "Cannibal States, Empty Bellies: Protest, History and Political Imagination in Post-Dayton Bosnia.” Critique of Anthropology 37 (3): 262-296.

Lazarević, Krsto. 2019. “A Young Man's Death in Bosnia.” Erstestiftung.Org, January 3, 2019. http://www.erstestiftung.org/en/ a-young-mans-death-in-bosnia/.

Lijphart, Arend. 1969. “Consociational Democracy.” World Politics 21 (02): 207-225.

Milan, Chiara. 2017a. "Reshaping Citizenship through Collective Action: Performative and Prefigurative Practices in the 20132014 Cycle of Contention in Bosnia \& Hercegovina.” Europe-Asia Studies 69 (9): 1346-1361.

Milan, Chiara. 2017b. "Sow Hunger, Reap Anger': From Neoliberal Privatization to New Collective Identities in Bosnia-Herzegovina." In Global Diffusion of Protest. Riding the Protest Wave in the Neoliberal Crisis, edited by Donatella Della Porta, 167-189. Amsterdam: Amsterdam University Press.

Milan, Chiara. 2020. Social Mobilization beyond Ethnicity: Civic Activism and Grassroots Movements in Bosnia and Herzegovina. Abingdon, UK: Routledge.

Mujanović, Jasmin. 2018. Hunger and Fury: The Crisis of Democracy in the Balkans. London: Hurst.

Mujkić, Asim. 2008. We, the Citizens of Ethnopolis. Sarajevo: Centar za ljudska prava Univerziteta.

Murtagh, Cera. 2016. “Civic Mobilization in Divided Societies and the Perils of Political Engagement: Bosnia and Herzegovina's Protest and Plenum Movement." Nationalism and Ethnic Politics 22 (2): 149-171.

Murtagh, Cera. 2020. “The Plight of Civic Parties in Divided Societies.” International Political Science Review 41 (1), 73-88. Sage Publications.

Nagle, John. 2008. “Challenging Ethno-National Division: New Social Movements in Belfast.” Social Movement Studies 7 (3): 305-318.

Nagle, John. 2016. Social Movements in Violently Divided Societies: Constructing Conflict and Peacebuilding. Vol. 173. London and New York: Routledge.

Nagle, John. 2017. “'One Community, Many Faces': Non-Sectarian Social Movements and Peace-Building in Northern Ireland and Lebanon." In The Troubles in Northern Ireland and Theories of Social Movements, edited by Lorenzo Bosi and Gianluca De Fazio, 185-201. Amsterdam: Amsterdam University Press.

Piacentini, Arianna. 2019a. “'Trying to Fit In': Multiethnic Parties, Ethno-Clientelism, and Power-Sharing in Bosnia and Herzegovina and Macedonia." Nationalism and Ethnic Politics 25 (3), 273-291.

Piacentini, Arianna. 2019b. "State Ownership and 'State-Sharing': The Role of Collective Identities and the Sociopolitical Cleavage between Ethnic Macedonians and Ethnic Albanians in the Republic of North Macedonia." Nationalities Papers 47 (3), 461-476.

Piacentini, Arianna. 2020. “'Nonaligned Citizens': Ethnic Power-Sharing and Nonethnic Identities in Bosnia Herzegovina. The Case of Sarajevo." Nationalities Papers 48 (1), 1-14.

Pita, Antonio. 2018. "El padre tenaz que cambió las elecciones en Bosnia." El País, October 6, 2018, sec. Internacional. https:// elpais.com/internacional/2018/10/06/actualidad/1538851083_149407.html.

Polletta, Francesca, and James M. Jasper. 2001. "Collective Identity and Social Movements." Annual Review of Sociology 27: 283-305. 
Pollozhani, Lura. 2016. "The Student Movement in Macedonia 2014-2016: Formation of a New Identity and Modes of Contention.” Südosteuropa Mitteilungen 5/6: 38-45.

Pugh, Michael. 2005. “Transformation in the Political Economy of Bosnia since Dayton.” International Peacekeeping 12 (3): 448-462.

Puljek-Shank, Randall, and Felix Fritsch. 2019. “Activism in Bosnia-Herzegovina: Struggles against Dual Hegemony and the Emergence of 'Local First." East European Politics and Societies 33 (1): 135-156.

Razsa, Maple. 2015. Bastards of Utopia: Living Radical Politics after Socialism. Bloomington: Indiana University Press.

Sasso, Alfredo. 2018a. "Demonstrating for David in Banja Luka." Osservatorio Balcani e Caucaso. https://www.balcanicaucaso. org/eng/Areas/Bosnia-Herzegovina/Demonstrating-for-David-in-Banja-Luka-187713. (Accessed May 10, 2018.)

Sasso, Alfredo. 2018b. "Pravda za Davida: 'Borimo se za našu živu djecu.”' Osservatorio Balcani e Caucaso. https://www. balcanicaucaso.org/bhs/zone/Bosna-i-Hercegovina/Pravda-za-Davida-Borimo-se-za-nasu-zivu-djecu-190358. (Accessed October 5, 2018.)

Sasso, Alfredo. 2019. "Banja Luka, assedio al movimento Pravda za Davida.” Osservatorio Balcani e Caucaso. https://www. balcanicaucaso.org/aree/Bosnia-Erzegovina/Banja-Luka-assedio-al-movimento-Pravda-za-Davida-191876. (Accessed January 7, 2019.)

Simpson, Tom. 2013. "Viva Bosnia!" https://tomsimpsonphd.wordpress.com/2013/06/22/viva-bosnia-2/. (Accessed June 22, 2013.)

Snow, David A., and C. Corrigall-Brown. 2015. “Collective Identity.” In International Encyclopedia of the Social \& Behavioral Sciences, 2nd ed., edited by James D. Wright, 174-180. Vol. 4. Oxford: Elsevier.

Snow, David A., E. Burke Rochford, Jr., Steven K. Worden, and Robert D. Benford. 1986. "Frame Alignment Processes, Micromobilization, and Movement Participation." American Sociological Review 51 (4): 464-481.

Stefanovski, Ivan. 2016. "From Shallow Democratization to Mobilization: The Cases of the 'Bosnian Spring' and the 'Citizens of Macedonia.” International Journal of Rule of Law, Transitional Justice and Human Rights 7: 43-52.

Surk, Barbara. 2019. "In Bosnia, a Father's Grief Swells into an Antigovernment Movement.” The New York Times, January 9, 2019. https://www.nytimes.com/2019/01/08/world/europe/bosnia-davor-dragicevic-milorad-dodik.html.

Tarrow, Sidney. 2011. Power in Movement: Social Movements and Contentious Politics. 3rd ed. Cambridge: Cambridge University Press.

Touquet, Heleen. 2011. "Multi-Ethnic Parties in Bosnia-Herzegovina: N Aša S Tranka and the Paradoxes of Postethnic Politics." Studies in Ethnicity and Nationalism 11 (3), 451-467.

Touquet, Heleen. 2012. Escaping Ethnopolis: Postethnic Mobilization in Bosnia-Herzegovina. PhD diss. Leuven, Belgium: Katholieke Universiteit Leuven.

Touquet, Heleen. 2015. "Non-Ethnic Mobilisation in Deeply Divided Societies, the Case of the Sarajevo Protests." Europe-Asia Studies 67 (3): 388-408.

Wimmen, Heiko. 2018. "Divided They Stand. Peace Building, State Reconstruction and Informal Political Movements in Bosnia-Herzegovina, 2005-2013.” In Social Movements in the Balkans: Rebellion and Protest in the Balkans, edited by Florian Bieber and Dario Brentin, 9-29. London: Routledge.

Zuvela, Maja. 2018. “Bosnia Families Bridge Ethnic Divide, Demand Justice for Dead Sons.” Reuters, May 15, 2018. https:// www.reuters.com/article/us-bosnia-protests/bosnia-families-bridge-ethnic-divide-demand-justice-for-dead-sons-idUSKC N1IG39H.

Cite this article: Milan, C. 2022. Navigating Ethnicity: Collective Identities and Movement Framing in Deeply Divided Societies. Nationalities Papers 50: 1057-1070, doi:10.1017/nps.2021.29 